DOI 10.4467/2543733XSSB.16.010.6252

\title{
WPLYW MNIEJSZOŚCI NARODOWYCH - GRECKIEJ W ALBANII I ALBAŃSKIEJ W GRECJI - NA RELACJE GRECKO-ALBAŃSKIE PO 1991 ROKU
}

\begin{abstract}
Słowa kluczowe: Albańczycy w Grecji, Grecy w Albanii, Bałkany, mniejszości narodowe, Omonia, Czameria (Czamuria)

Przedmiotem artykułu jest ukazanie roli, jaką spełniają mniejszości - z jednej strony grecka, żyjąca w Albanii, z drugiej zaś albańska - w Grecji, w generowaniu konfliktów lub ich wyciszaniu, czyli zobrazowanie ich wpływu na wzajemne relacje między Atenami i Tiraną. W tym celu wykorzystano teorię instrumentalnego ujęcia konfliktów na tle narodowym i religijnym, które tacy uczeni jak: A. Cohen, Anthony D. Smith, Stephan Cornell i Dauglas Hartmann ${ }^{1}$ uważają w obecnej dobie za najistotniejszą kwestię dla badań nad antagonizmami. Uznają oni bowiem, że spory powstające na tle etnicznym i religijnym są w dużej mierze kreowane przez elity polityczne, liderów politycznych, którzy wskazują na odmienną tożsamość kulturową, religijną, narodową - czyli specyfikę poszczególnych grup, których świadomość wspólnotowa jest niezaprzeczalna² ${ }^{2}$ Podstawowym celem nie jest zatem odpowiedź na pytanie, jak dalece różnorodność poszczególnych regionów (zwłaszcza pogranicza) i wspólnot jest czynnikiem wystarczającym, by do konfliktów dochodziło, ale w jakim stopniu polityka poszczególnych państw ma wpływ na łagodzenie, a nawet zapobieganie, czy też odwrotnie, celowe podtrzymywanie konfliktów czy wręcz ich kreowanie. Niezbędnym instrumentem w realizacji tych procesów jest odwoływanie się władzy, elit politycznych czy też ich liderów do „zbiorowej nazwy własnej, wspólnego pochodzenia, kultywowania pamięci historycznej, jednego lub wielu elementów wspól-

1 A. Co he n, Two-dimensional man: An essay on power and symbolism in complex society, London 1974; S. Corne11, D. Hartmann, Ethnicity and Race: Making Identities in a Changing World, Thousand Oaks, 1998; A. D. S mit h, Nationalism: Theory, Ideology, History, Polity, Cambridge 2001.

${ }^{2} \mathrm{P}$. B a l c e r o w i c z, Czy istnieja konflikty etniczne i religijne?, [w:] Zaawansowane zapobieganie konfliktom, red. W. Kostecki, Warszawa 2011, s. 42 i n.
\end{abstract}


nej kultury, do związków z określoną 'ojczyzną' i do pewnego stopnia solidarności”’’. Najważniejszym zadaniem będzie wykazanie, że tak w Grecji, jak i w Albanii doszło do wyraźnego uzależnienia polityki mniejszościowej od historii, a także jej wykorzystania w bieżącej polityce zagranicznej obydwóch państw.

\section{I}

W Grecji, w której od pokoleń żyją mniejszości narodowe i etniczne, odmawia się im oficjalnego uznania, jednak Ateny prowadzą wobec nich coraz bardziej tolerancyjną politykę, wynikającą ze stanowiska Unii Europejskiej, i przyjmują zasadę, że każdy obywatel Grecji bez przeszkód może dokonywać samoidentyfikacji. Niemniej problem ten jest ściśle związany z prawem do zrzeszania się i uzyskania przez członków powstających w ten sposób wspólnot (religijne, językowe, etniczne) osobowości prawnej. Tylko grupy mające takie uprawnienia mogą oficjalnie funkcjonować, gromadzić fundusze i być reprezentowane w sądzie. Nie dotyczy to grup narodowych takich jak: Turcy, Albańczycy, Macedończycy i Bułgarzy, którzy żyją w Grecji. Określanie narodowe inne niż greckie nie jest uznawane.

Podstawę polityki państwa stanowi założenie, że jednolity pod względem etnicznym kraj buduje naród grecki, wyznający prawosławie i mówiący językiem greckim. Z tej przyczyny nie prowadzi się oficjalnych statystyk mniejszości, zaś badacze wspomnianej problematyki zakładają, że mniejszości religijne i narodowe obejmują obecnie od 5 do 10 procent ogólnej liczby mieszkańców Grecji. Na przykład Hugh Poulton podaje, że współczesna Grecja jest sumą różnych cywilizacji i narodów:

Po pewnym czasie większość populacji - być może 95 procent - będzie etnicznie grecka i to jest faktem, którego często nie daje się wytłumaczyć, następuje także znaczne zhellenizowanie mniejszości - Wołochów, Turków, Pomaków, Cyganów, Albańczyków, »Macedończyków« i innych ${ }^{4}$.

Tadeusz Czekalski twierdzi natomiast:

Grecja jest jedynym spośród krajów bałkańskich, który nie uznaje na swoim terytorium mniejszości narodowych, mimo że odsetek ludności mówiącej innymi językami niż grecki jest szacowany na 10 procent populacji ${ }^{5}$.

Powodem nieuznawania przez Grecję różnych grup narodowych, religijnych i językowych była chęć ugruntowania niepodległości odzyskanej w 1830 roku, a potem zjednoczenia prowincji o zróżnicowanym stopniu świadomości narodowej i poziomie cywilizacyj-

${ }^{3}$ Ibidem, s. 43; A.D. S mith, Nationalism: Theory, Ideology..., s. 109; D. S mith, Trends and Causes of Armed Conflict, http://edoc.vifapol.de/opus/volltexte/2011/2576/pdf/smith_handbook.pdf, Edited version Aug. 2004, s. 11, (dostęp: 20.01.2016); M. W a l e n b e rg, Narody zależne i mniejszości narodowe w Europie Środkowo-Wschodniej. Dzieje konfliktów idei, Warszawa 2000, s. 16, 17. Jest to inne od przedstawionego przez H. Batowskiego w rozmowie z R. Bilskim podejście do przyczyn generowania na Bałkanach konfliktów: ,,...tradycja, sposób myślenia, moralność bizantyjska, tj. bezwzględność oraz stanowcze dążenie do absolutnej dominacji, przetrwały na Bałkanach przez stulecia od upadku cesarstwa wschodniorzymskiego do czasów współczesnych". Zob. R. B ils k i, Nie strzelajcie do nocnego ptaka. Batkany 1991-1998, Warszawa 1998, s. 143.

${ }^{4}$ H. Poult o n, The Balkans Minorities and States in Conflict, London 1993, s. 175.

${ }_{5}^{5}$ J. Bonarek, T. Czekalski, S. S praw ski, S. Turlej, Historia Grecji, Kraków 2005, s. 643. 
no-kulturowym. Na Bałkanach, gdzie rozwiązywanie konfliktów etnicznych przybierało i do dzisiaj często przybiera bardzo drastyczne formy, Grecy, chcąc te wydarzenia antycypować, posuwali się do rozmaitych metod, jak np.: wymiana ludności, zmiana nazwisk i edukacja w duchu narodowym. Tym samym deklarowali jedność etniczną swego kraju. Nie tylko państwo greckie, również społeczeństwo, ma negatywny stosunek zarówno do mniejszości narodowych i religijnych, jak i imigrantów, uchodźców i azylantów.

Powstanie niepodległej Albanii i podział, na mocy protokołu florenckiego z 17 grudnia 1913 roku, Epiru na dwie części pogłębiły niezadowolenie Grecji, zwłaszcza że dwa duże miasta, do których pretendowały Ateny: Korcza (alb. Korçë) i Gjirokastra (alb. Gjirokastër), znalazły się w granicach Albanii. Grecja nigdy takiego rozstrzygnięcia nie zaakceptowała, argumentując, że względy ekonomiczne i demograficzne przemawiają za przyznaniem jej wspomnianych terenów. Dla Albanii jest to obszar bardzo ważny z punktu widzenia gospodarczego, politycznego i strategicznego, zwłaszcza że leżąca na południe od wyznaczonej granicy albańsko-greckiej tzw. Czameria (Czamuria), w dużej mierze zamieszkała przez Albańczyków, przypadła Grecji. Albańczyk Rigels Halili, piszący w języku polskim, stwierdził:

Z kolei Grecja zaanektowała Çamërię (Czamerię) na południu. Legenda głosi, że ponoć usłyszawszy wieści z Londynu, człowiek, który ogłosił niepodległość Albanii i stał na czele jej pierwszego rządu - Ismail Qemali - miał rzec „zostawili nam same góry”.

O granicach Albanii i jej zasięgu terytorialnym nie decydowali przecież sami Albańczycy, lecz mocarstwa, kierujące się przede wszystkim swoimi interesami na Bałkanach, z pominięciem uwag i pretensji zarówno greckich, jak i albańskich?

Albańczycy, którzy żyją w Grecji od pokoleń, to Arwanici, zwani także Albanofonami. Ta ostatnia nazwa funkcjonuje dlatego, iż Grecy nie uznają, że w ich kraju mieszkają Albańczycy, sami też Arwanici na skutek asymilacji nie zawsze przyznają się do albańskiego pochodzenia. Tworzą oni niewielkie skupiska ludności w okolicach Koryntu, Argos, a także w Beocji i Attyce oraz na Wyspach Jońskich i w Tracji. Jeśli chodzi o ich liczbę, to badacze szacują, że w centralnej Grecji żyje 140 tys. Albańczyków, natomiast w Tracji Zachodniej ok. 30 tys. $^{8}$ Posługują się licznymi dialektami albańskimi - toskijskimi (południowymi), które powszechnie postrzegane są jako wzajemnie niezrozumiałe. $\mathrm{Na}$ co dzień mówią po grecku, natomiast w Tracji Zachodniej również po turecku. Ich sytuacja porównywalna jest do losów Wołochów w Grecji. Polityka asymilacyjna i migracja do dużych miast utrudniają kontakt $\mathrm{z}$ własnym środowiskiem. W latach osiemdziesiątych społeczność albańska z racji polityki Unii Europejskiej zintensyfikowała działalność kulturalną, dzięki czemu powstało kilka towarzystw, jak: Arwanicki Związek Grecji (A $\lambda \beta \alpha v i \kappa \eta ́ \varsigma ~ \Sigma u ́ \lambda \lambda o \gamma o \varsigma$ E $\lambda \lambda \alpha \dot{\alpha} \delta \alpha$ ), który wydaje dwumiesięcznik „Besa”, Centrum

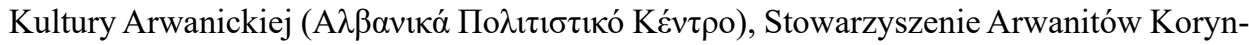

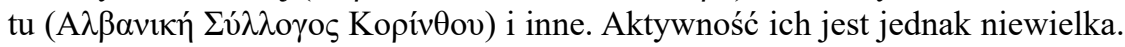

Inną grupą Albańczyków w Grecji są Czamowie, których nazwa pochodzi od obszaru

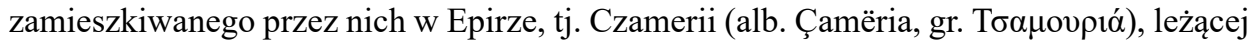

${ }^{6}$ R. Halili, Naród i jego pieśni. Rzecz o oralności, piśmienności i epice ludowej wśród Albańczyków i Serbów, Warszawa 2012, s. 68.

${ }^{7}$ I. S ta w ow y-Kaw ka, Albańczycy w Macedonii 1944-2001, Kraków 2014, s. 29-35.

${ }^{8}$ P. H i1l, Mehrsprachkeiten in Südosteuropa, „Zeitschrift für Balkanologie”, J. 1990/26, s. 64; P. Tru dgi11, On Dialect: Social and Geographical Perspectives, Oxford 1983, s. 135. 
w większości w Grecji, w prefekturze Tesprotia. Tylko niewielki skrawek Czamerii przekracza granicę albańską. Jest to obszar konfliktu między Atenami i Tiraną, ze względu na kwestię wzajemnego traktowania mniejszości narodowych, żyjących w tej części Grecji, ale także w południowej Albanii. W czasach imperium osmańskiego w zamieszkiwanym głównie przez Albańczyków Epirze osiedlali się także Grecy. W okresie greckiego odrodzenia narodowego obszarem tym zainteresowały się Ateny; w dodatku Grecy nigdy nie traktowali Albańczyków jako narodu, który potrafi stworzyć własne państwo.

Bardzo trudno dzisiaj oszacować liczbę albańskojęzycznej ludności zamieszkującej Czamerię. Grecja bowiem nie uznaje tej ludności za Albańczyków i nie prowadzi statystyk odzwierciedlających stan faktyczny. Funkcjonująca w USA organizacja - Democratic Cameria League szacuje liczbę Czamów na około 100 tys. ${ }^{9}$, natomiast Organizacja Mniejszości Europejskich (Organization for the European Minorities) na 65 do 100 tys. $^{10}$

W przeszłości Grecja zarówno w Południowym Epirze jak i południowej Macedonii, tj. na obszarach zdobytych w 1913 roku w wyniku wojen bałkańskich, prowadziła politykę mającą na celu zmniejszenie liczby Albańczyków w tym regionie. W czasie II wojny światowej Albańczycy - muzułmanie opowiedzieli się po stronie Włoch, za co zostali ukarani - według obliczeń albańskich ok. 2-5 tys. poniosło śmierć ${ }^{11}$, spalono 61 wsi z 5800 domostwami, a 22 tys. ludzi musiało uciekać do sąsiedniej Albanii, gdzie mimo pomocy Czerwonego Krzyża i UNRRA (Administracja Narodów Zjednoczonych do spraw Pomocy i Odbudowy) aż 2 tys. z nich zmarło z powodu chorób i głodu ${ }^{12}$. Grecy zgodzili się, by pozostali tylko wyznawcy prawosławia. Po wojnie Tirana domagała się, żeby pozwolić wysiedlonej ludności na powrót do pozostawionych w Grecji domostw, ale bez skutku ${ }^{13}$. W 1991 roku dyplomacja albańska oszacowała swoje roszczenia majątkowe pod adresem państwa greckiego na 350 mln dolarów USA według stanu z 1945 roku, tj. 2,5 mld w cenach aktualnych ${ }^{14}$. Upominano się również o dobytek utracony przez uciekających z Grecji Albańczyków, a nawet o autonomię kulturalną dla Albańczyków w Czamerii. W 1992 roku w miejscowości Konispoli, położonej w północnej Czamerii na terytorium Albanii, odsłonięto pomnik ofiar ludobójstwa, którego dopuszczono się na Czamach. Tu każdego roku Albańczycy organizują uroczystości upamiętniające wydarzenia II wojny światowej, śmierć rodaków i ich uchodźstwo. O tym przypomina też corocznie 27 czerwca, w dniu święta Czamów, Narodowo-Polityczne Stowarzyszenie Czameria (alb. Shoqëria Politike Atdhetare Çamëria), założone w Tiranie 10 stycznia 1991 roku. Ilekroć polityk z Aten pojawia się w Tiranie, manifestuje grupa Czamów, by przypomnieć o ich nierozwiązanych problemach w Grecji. Sprawę zaognia fakt, że społeczeństwo greckie do tej pory nie pogodziło się z utratą Epiru Północnego, a powszechnym zjawiskiem jest nazywanie

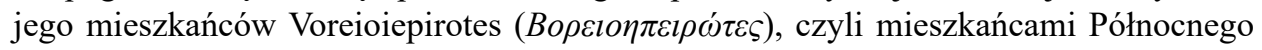

\footnotetext{
${ }_{9}^{9}$ Democratic Cameria League, https://www.youtube.com/watch?v=DMJ7R6RJJfQ, (dostęp: 20.01.2016).

${ }^{10}$ Organization for the European Minorities, http://www.eurominority.org/version/eng/minotity-detail. asp?id_pays=19\&id_minorites=gr-alba, także: http://archive.today/www.eurominority.org, (dostęp: 20.01.2016).

${ }^{11}$ T. C z e ka1s k i, Pótnocny Epir i Czamuria - współczesne oblicze sporu grecko-albańskiego, [w:] Naród - państwo - Europa Środkowa w XIX i XX wieku, red. A. Patek i W. Rojek, Kraków 2006, s. 312.

${ }_{12}$ Stenogrami od OON (34), Šeeset i četvrta sednica održana vo Lake Success, New Jork vo ponedelnik, 9 septemvri 1946 godina vo 15 časot, w: „Fokus”, 2/1/2001, s. 50.

${ }^{13}$ M. Vi ck e r s, The Cham Issue: Albanian National and Property Claims in Greece, 2002, http://www. albanianhistory.net/texts21/AH2002_1.html, (dostęp: 20.01.2016) .

${ }^{14}$ T. Czekals ki, Pólnocny Epir i Czamuria..., s. 312.
} 
Epiru. Albania unika używania tej nazwy, gdyż uważa, że nawiązuje do sytuacji z 17 maja 1914 roku i protokołu z Korfu, gdy region uzyskał autonomię, a co za tym idzie, pokazuje greckie roszczenia autonomistyczne i terytorialne. Nadto gdy po przymusowej ateizacji Albanii w okresie rządów komunistycznych nadeszła transformacja, to kler grecki przejął inicjatywę wskrzeszenia w Albanii prawosławia, natomiast grecka mniejszość tworzyła

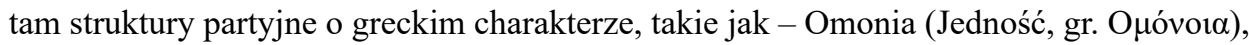
której pełna nazwa brzmi: Demokratyczny Związek Mniejszości Greckiej „Omonia”

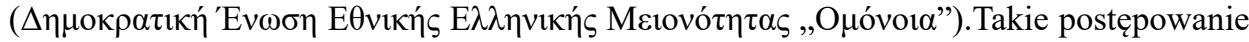
Greków budzi niepokój w Tiranie. Czamowie w Grecji nie mają swych szkół, a nauczanie dzieci i młodzieży odbywa się w języku greckim.

\section{II}

Natomiast w Albanii prawodawstwo mniejszościowe dopiero jest tworzone. Zgodnie $\mathrm{z}$ nadal obowiązującym, zatwierdzonym w czasach komunizmu prawem przyjmuje się regułę, że mniejszości narodowe żyją tylko w tzw. strefach mniejszościowych. W stosunku do przyjmowania obywatelstwa albańskiego lub obcego, rząd w Tiranie zastosował zasadę zgodną z deklaracją Ligi Narodów, podpisaną przez Albanię 2 października 1921 roku, i do tej pory powołuje się na to prawne rozwiązanie. Wówczas to w ciągu 2 lat od wprowadzenia w życie postanowień deklaracji obywatele mogli złożyć oświadczenie, że wprawdzie nie są pochodzenia albańskiego, ale chcą żyć w Albanii - np. Grek żyjący w Albanii. Sporządzony na tej podstawie Krajowy Rejestr Stanu Cywilnego (Regjistri Kombëtar i Gjendjes Civile) obowiązuje do dzisiaj i jeśli ktoś jest w nim zapisany jako obywatel kraju, nie ma podstaw do zmiany obywatelstwa albańskiego na inne. Natomiast narodowość jest zgodna z obywatelstwem rodziców, a tożsamość każdego obywatela ustala urząd. Każdy obywatel Albanii ma swój numer ID, który określa tożsamość, obywatelstwo, stan cywilny i prawny. Reguluje to ustawa nr 10129 z dnia 5 listopada 2009, art. $58^{15}$. Dane dotyczące obywatelstwa są przez władze w Tiranie wykorzystywane do sporządzenia statystyk na temat pochodzenia etnicznego i narodowego ludności ${ }^{16}$. Przy definiowaniu mniejszości w Albanii następnymi kryteriami przynależności do danej grupy są: język, wyznawana religia i miejsce urodzenia $w$ strefie etnicznej. W Albanii podkreśla się, że dla dobra obywateli odstąpiono od zasady z 1921 roku i w czasie spisu ludności w roku 2011 pozwolono na swobodne określanie swej przynależności kulturalnej, etnicznej i religijnej ${ }^{17}$. W maju 2011 roku zniesiono praktykę obowiązkowej rejestracji w aktach urodzenia pochodzenia etnicznego przez osoby należące do mniejszości greckiej i macedońskiej. Nie uczyniono jednak tego wobec wszystkich obywateli Albanii. Na terytorium kraju poza strefami mniejszościowymi obowiązuje wpis do Krajowego Rejestru Stanu Cywilnego. Rada Europy w Rezolucji CM / Res CMN (2014) o wdrażaniu przez Albanię Ramowej Konwencji stwierdziła, że przepis ten narusza prawa innych mniejszości i je

\footnotetext{
${ }^{15}$ Aktet që kanë ndryshuar aktin e mësipërm, http://80.78.70.231/pls/kuv/kerkim_ndryshime2?a_emertimi_ligjit=Ligj\&a_numri_aktit=10129\&a_viti_aktit=11.05.2009, (dostęp: 20.01.2016).

${ }^{16}$ Minoritetet etnike në Shqioëri, http://open.data.al/sq/lajme/lajm/lang/sq/id/673/Minoritetet-etnike-ne-Shqiperi, na stronach: Open Data - fundacionetic.org, (dostęp: 6.10.2015).

17 Ibidem.
} 
dyskryminuje (Resolution CM/ResCMN (2014)). Zatem realnie prawa mniejszości obowiązują wyłącznie na obszarach uznawanych za strefy mniejszościowe.

W Albanii Grecy zamieszkują przede wszystkim południową część kraju, tj. Północny Epir. Za rządów komunistycznych rozmieszczenie tej ludności uległo zmianie, ponieważ władzom zależało na osiedlaniu wśród Greków ludności albańskiej. Ustawodawstwo, wprowadzane stopniowo od 1949 roku, aktualizowane w latach 1950 i 1960, oraz dekret nr 5912 z 26 czerwca 1979 roku o internowaniu tych, którzy stanowią na danym terenie zagrożenie dla istniejącego systemu społecznego, były wobec mniejszości greckiej często stosowane. Z powyższych rozwiązań korzystano także w stosunku do osób, których krewni uciekli za granicę. W ramach programu ,,mobilizacji obywatelskiej”, Greków osiedlano najczęściej w północnej Albanii, co oznaczało przymus pracy na stanowisku i miejscu wskazanym przez władze partyjne. Dobytek pozostawiony przez Greków przejmowały zasłużone w walce partyzanckiej rodziny albańskie ${ }^{18}$. Jak było zaznaczone, obecnie większe skupiska ludności greckiej znajdują się w południowej części kraju, wzdłuż granicy z Grecją. Grecy nazywają go Północnym Epirem.

Liczbę Greków żyjących w Albanii bardzo trudno określić - oficjalnie albańskie dane ze spisu ludności w 2011 roku mówią, że jest ich 24 243. Tymczasem Hugh Poulton ich liczbę ocenia na ok. 40 tys. $^{19}$, co stanowi ok. 2,4\% społeczeństwa albańskiego. Natomiast greccy badacze podają liczbę 60 tys., z kolei w raporcie Departamentu Stanu z 2003 roku liczbę tę szacowano na 60 do 70 tys., niemniej ze względu na dużą emigrację po 1991 roku, gdy Albania otwarła granice, liczba ta ulegała zmniejszeniu ${ }^{20}$. Ponieważ wspomniane osoby noszą greckie nazwiska, mówią po grecku ${ }^{21}$ i należą też do prawosławnego ortodoksyjnego Kościoła, bardzo często wszystkich wyznawców tej religii, bez względu na tożsamość narodową, określano jako Greków. Są wśród nich nie tylko Albańczycy, którzy żyjąc wśród greckiej ludności, nauczyli się języka greckiego, by uzyskać wizę grecką, ale także Wołosi. Z tego powodu niektóre statystyki mówią nawet o 400 tys. Greków w Albanii, co nie jest właściwe, jednak ustalenie dokładnej liczby tej mniejszości leży w interesie samej Tirany, ze względów historycznych.

Największe skupiska Greków w Albanii znajdują się w obwodach: Sarandë, Gjirokastër

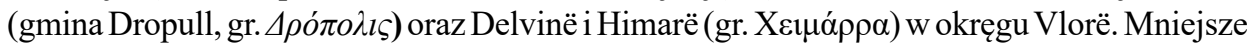
grupy zamieszkują okręgi: Kolonjë, Permet, Korçë. Ponadto wielu Greków żyje w dużych miastach, takich jak: Tirana, Fier, Durrës, Elbasan, Shkodër. Dzisiaj obszary te częściowo opustoszały, gdy po otwarciu granic w 1991 roku młodzi ludzie wyruszyli do pracy w Grecji, pozostawiając jedynie starszych, by na miejscu pilnowali ich dobytku. Niemniej z powodu kryzysu w Grecji część z nich, nie mogąc tam znaleźć pracy, powróciła już do Albanii.

Obecnie Grecy żyjący w mieście Himarë i wsiach tej gminy, jak: Dhërmi (gr. $\Delta \rho v$ -

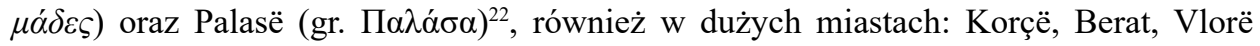

${ }^{18}$ H. Poulton, The Balkans Minorities..., s. 198.

19 Ibidem, s. 195.

${ }^{20}$ Albania, Country Information - US Department of Justice, http://www.justice.gov/sites/default/fi les/ eoir/legacy/2014/10/21/0403_Albania.pdf, (dostęp: 20.01.2016).

${ }^{21}$ Grecy w Albanii posługują się dialektem greckim, który zachował pewne archaiczne formy i słowa oraz posiada wiele albańskich zapożyczeń. Nie jest on jednolity na terenie Albanii, poszczególne miejscowości zachowują językową dialektyczną specyfikę, najbardziej zauważalną w akcencie.

${ }^{22}$ Chodzi o Himarë i sześć wiosek wokół miasta. 
czy Tirana - leżących poza strefami mniejszościowymi, nie mają praw, które należą się mniejszościom.

Od 1933 r., kiedy król Zogu zamknął wszystkie szkoły dla obywateli mniejszości, nie było na terenie Albanii edukacji w języku greckim. W ten sposób art. 5 deklaracji Ligi Narodów, stanowiący, że wszyscy obywatele są równi wobec prawa niezależnie od rasy, przynależności religijnej lub językowej i będą tak samo traktowani oraz objęci takim samym systemem prawnym nie był wypełniany. Przede wszystkim chodziło o to, że mniejszości powinny mieć takie samo jak inni obywatele prawo do utrzymania na własny koszt instytucji religijnych, społecznych i charytatywnych, oraz zarządzania nimi, a także do posiadania szkół i placówek edukacyjnych z możliwością używania własnego języka i praktykowania religii ${ }^{23}$. Od 1933 r., wbrew przyjętym zobowiązaniom, Albania nie przestrzegała wspomnianych praw mniejszości, mimo że Stały Trybunał Sprawiedliwości Międzynarodowej (STSM, ang. Permanent Court of International Justice, fr. Cour permanente de Justice internationale) 6 kwietnia 1935 roku (PCIJ /B 64) wydał wyrok, iż takie postępowanie narusza zasady równego traktowania obywateli, prowadzi do dyskryminacji i zakłóca równowagę między różnymi grupami społecznymi ${ }^{24}$. Wprawdzie w pierwszych latach po wojnie funkcjonowały nieliczne greckie szkoły podstawowe i średnie w tzw. strefach mniejszościowych, ale nauczano w nich literatury i historii albańskiej, umacniając reżim Envera Hodży. Albania znowu zaczęła wypełniać zobowiązanie do prowadzenia edukacji w języku greckiej mniejszości w 1994 roku, kiedy założono 15 greckich szkół. W późniejszym czasie, zwłaszcza po 1996 roku, w strefach mniejszościowych uznanych przez władze w Tiranie powstały następne, w rezultacie w każdej wsi istnieje taka szkoła. Oprócz tego w Korczy (alb. Korçë) w 2005 roku otwarto dwujęzyczną albańsko-grecką szkołę, a w 2006 roku w Himarë - szkołę grecką. Aby zapewnić tym szkołom odpowiednią kadrę, na Uniwersytecie w Tiranie otwarto wydział z greckim językiem wykładowym, a w 2006 roku w Gjirokastër na południu Albanii uniwersytet, który jednak z powodu niewielkiej liczby studentów i braku nauczycieli akademickich został zamknięty ${ }^{25}$. Na zarzut, że system nauczania dla mniejszości greckiej nie jest zadowalający, władze odpowiadają, że ludność albańska w Grecji w ogóle jest pozbawiona takiej nauki.

Grecy w Albanii wydają dwa czasopisma w języku greckim: „Laiko Vima” oraz „Zeri i Omonia". Mają też dostęp do prasy greckiej.

\section{III}

Na traktowanie i status mniejszości greckiej w Albanii oraz Albańczyków w Grecji w dużej mierze wpływają wzajemne relacje między obu krajami.

Podczas greckiej wojny domowej (1944-1949) przez Albanię - służącą jako baza dla komunistycznych partyzantów - wielu komunistów greckich i macedońskich prze-

${ }^{23}$ Office of the High Commissioner on Human Rights, Zays Alfred de, The International Judicial Protection of the Rights of Peoples and Minorities, http://alfreddezays.com/Chapbooks/AMSTERDAM.shtml, (dostęp: 20.01.2016).

24 Ibidem.

25 Studia w Gjirokastër miały być finansowane przez rząd grecki. Nauka trwała tu do 2010 r., zob. M. Vickers, The Greek Minority in Albania..., s. 6. 
dostało się do krajów bloku wschodniego, niektórzy osiedlili się w Albanii. Jeszcze za życia Hodży, w maju 1971 roku Albania i Grecja wznowiły stosunki dyplomatyczne, ale nie wcześniej niż po śmierci dyktatora w 1985 roku nastąpiła faktyczna poprawa bilateralnych relacji. W sierpniu 1987 roku rząd grecki oficjalnie zniósł utrzymujący się od inwazji włoskiej w 1941 roku stan wojny z Albanią. W listopadzie 1987 roku oba państwa podpisały szereg porozumień o współpracy. Jednak dopiero w latach 90., gdy doszło do demokratyzacji Albanii, nastąpiła nowa sytuacja polityczna. Pierwszą organizacją mniejszości greckiej w Albanii była wspomniana już Omonia, która promowała prawa mniejszości greckiej i domagała się, by Albania przyznała Północnemu Epirowi autonomię. Energiczne działania Omonii, założonej w 1991 r. we wsi Derviçan ${ }^{26}$, szybko doprowadziły do poszerzenia jej elektoratu i powstania wielu sekcji tej organizacji: w Sarandë, Dalvinë, Gjirokastër i Tiranie, i podsekcji w Korçë, Vorë i Permet. Omonia brała czynny udział już w pierwszych wielopartyjnych wyborach w Albanii, w których odniosła sukces, ponieważ na 250 miejsc w parlamencie zdobyła 5. Jej działania zostały jednak szybko zakwestionowane przez komisję wyborczą, gdyż w następnym roku w przedterminowych wyborach parlamentarnych obowiązywała już nowa ordynacja wyborcza, która zabraniała tworzenia partii politycznych na podstawie etnicznej lub religijnej. Omonia była typowo grecką partią ${ }^{27}$. W wyniku interwencji Grecji i UE przedstawiciele mniejszości greckiej startowali w 1992 roku z list Unii na rzecz Praw Człowieka (alb. Partia

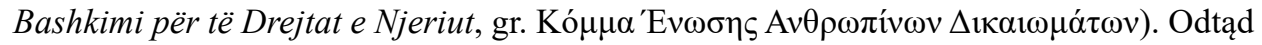
partia ta reprezentuje grecką mniejszość w parlamencie i współpracuje z Omonią. Od roku 2002 na czele partii, zyskującej w kolejnych wyborach od 2 do 4 przedstawicieli, stoi Vangjel Dulè. Grecy często zajmują wysokie stanowiska w administracji państwowej, i nawet w rządzie. Np. 3 października sędzią Sądu Najwyższego został prof. prawa karnego z Uniwersytetu w Tiranie, Spirou Siros. Także w strukturach władz lokalnych Grecy mają swą reprezentację, np. w obwodzie Sarandë ośmiu z dwudziestu czterech przedstawicieli to Grecy.

Omonia nadal prowadzi działalność, lecz postrzegana jest w Tiranie jako skrajnie nacjonalistyczna grecka organizacja kulturalno-polityczna, co powoduje, że Albańczycy mają ustalony pogląd na temat żądań greckiej mniejszości:

Jedynym sposobem, aby spełnić prawa mniejszości greckiej w Albanii, jest autonomia, a może nawet w przyszłości połączenie „Północnego Epiru” z Grecją ${ }^{28}$.

Te obawy Tirany są najczęściej powtarzanym argumentem w rozmowach o prawach mniejszości greckiej, nazywanej przez Albańczyków trudnym rozmówca.

Gdy w 1993 roku usunięto z Albanii prawosławnego archimandrytę Chrysostomosa Maidonisa, oskarżonego o podsycanie separatyzmu w Północnym Epirze, władze Aten wydaliły z Grecji ponad 20 tys. albańskich emigrantów przebywających tam nielegalnie. Do dalszego zaognienia relacji albańsko-greckich doszło w lipcu 1994 r., kiedy grupa ośmiu uzbrojonych osób napadła na posterunek strażnicy granicznej w Peshkopii, za-

${ }^{26}$ M. Vi ckers, The Greek Minority in Albania - Current Tensions, „Balkans Series” 10/02, http://www. voltairenet.org/IMG/pdf/Greek_minority_in_Albania.pdf, (dostęp: 20.01.2016), s. 6.

27 Ibidem, s. 5.

28 A. A z i zaj, Çështja e minoriteteve në plnin ndërkombëtar, për mbrojtjen e diplomës, Vlorë 2009, s. 43. 
bijając dwóch żołnierzy albańskich. Odpowiedzialność za atak przyjął na siebie Front

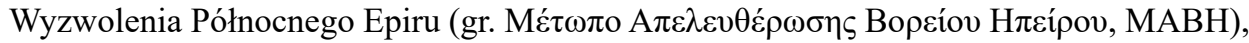
organizacja w swej nazwie nawiązująca do greckiego ruchu oporu działającego w czasie II wojny światowej. Grecja zaprzeczyła, jakoby miała jakikolwiek udział w tym incydencie. W rezultacie dokonanych przez albańską policję przeszukań w pomieszczeniach Omonii, we wrześniu 1994 roku władze albańskie skazały pięciu jej członków na 6-8 lat więzienia za rzekome szpiegostwo na rzecz Grecji. W reakcji na to Grecja wydaliła 70 tys. nielegalnych imigrantów albańskich i zablokowała pożyczki UE dla Albanii. Miranda Vickers twierdzi, że działacze Omonii otwarcie popierają akcje $\mathrm{MABH}^{29}$.

W lutym 1995 roku albański sąd najwyższy zwolnił warunkowo działaczy Omonii, po tym jak 21 marca 1995 roku grecki minister spraw wewnętrznych Stelios Papathemelis poinformował o ujęciu siedmiu osób podejrzanych o atak ma posterunek w Peshkopii. Dowódcą miał być Anastasios Giorgos, były oficer armii greckiej ${ }^{30}$. Współpraca z władzami w Atenach w sprawie ustalenia sprawców zamachu doprowadziła do poprawy wzajemnych relacji międzypaństwowych i wpłynęła na polepszenie stosunków albańsko-greckich, co w konsekwencji umożliwiło podpisanie Układu o przyjaźni, wspótpracy i dobrym sasiedztwie. Jednak w relacjach wewnętrznych nadal dochodziło do nieporozumień między obu społecznościami: grecką i albańską. 12 sierpnia 2010 roku sklepikarz greckiego pochodzenia Aristotelis Goumas został potrącony przez samochód prowadzony przez trzech młodych Albańczyków. Wcześniej posprzeczali się w sklepie o język, w którym Goumos obsługiwał klientów. Śmierć sklepikarza w wyniku wypadku wywołała szereg protestów społeczności greckiej w Albanii, łącznie z żądaniem zwiększenia reprezentacji greckiej w policji w miejscowości Himarë.

Wzrost działań nacjonalistycznych grup albańskich w tych regionach Albanii, które są zamieszkałe przez mniejszości, zanotować można było po 2008 roku, gdy została ogłoszona niepodległość Kosowa. Co najmniej dwukrotnie przeprowadzono zamachy bombowe na budynek władz miasta Himarë, kiedy burmistrzem był Vasi Bollano, z pochodzenia Grek ${ }^{31}$. Dopiero po długich negocjacjach między przedstawicielami mniejszości i rządem pozwolono na wprowadzenie dwujęzycznych znaków drogowych w strefach mniejszościowych. Grecy walczą o wprowadzenie języka greckiego jako państwowego na równi z albańskim. Często dochodzi do demonstracji tak Greków, jak i Albańczyków, którzy podkreślają, że terytoria Północnego Epiru im właśnie się należą. Prowokacjom $\mathrm{i}$ incydentom towarzyszą niejednokrotnie agresywne zachowania, zwłaszcza w miejscowości Himarë. Gdy Bollano nakazał usunięcie znaków drogowych w języku albańskim i pozostawienie jedynie greckich, władze w Tiranie uznały ten krok za przekroczenie uprawnień burmistrza; w rezultacie sąd we Vlorë skazał go na sześć miesięcy więzienia, karę pieniężną i zakaz pełnienia funkcji przez trzy lata ${ }^{32}$. Najwięcej kontrowersji budził przeprowadzany w Albanii w 2011 roku powszechny spis ludności, do którego bojkotu

${ }^{29}$ M. Vickers, The Greek Minority in Albania..., s. 7.

${ }^{30}$ J. Pe t t i fer, The Greek Minority in Albania. Ethnic Minority in Post-communist State, [w:] The Politics of National Minority Participation in Post-communist Europe: State-building, Democracy, and Ethnic Mobilization, red. J.P. Stein, New York 2000, s. 188.

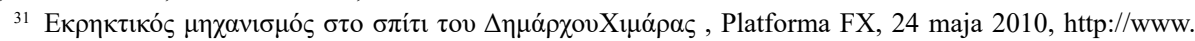
zougla.gr/page.ashx?pid=2\&aid=138350\&cid=4, (dostęp: 20.01 .2016 ).

${ }^{32}$ M. Vickers, The Greek Minority in Albania..., s. 9. 
wezwała Omonia, ponieważ przedstawicielom mniejszości grożono grzywną za podanie innej narodowości, niż zostało to wpisane w dowodzie.

Jak wskazuje badaczka dziejów Albanii - Miranada Vickers, sytuacja Greków w Albanii jest o wiele lepsza niż innych mniejszości w tym kraju, a często także samych Albańczyków. Ci mogą bez problemu uzyskiwać wizy do Grecji, kształcić tam swoje dzieci i pracować, korzystać z pomocy lekarskiej, a nawet dostawać emeryturę, na którą w Grecji nie zapracowali3 ${ }^{33}$.

\section{Podsumowanie}

Za najpilniejsze działania prowadzące do poprawy sytuacji mniejszości greckiej w Albanii uznać należy:

1. Całkowite zniesienie tzw. stref mniejszościowych ${ }^{34}$, tak aby na terenach zamieszkałych przez Greków można było otwierać prywatne i państwowe szkoły greckie i aby dane uzyskane na podstawie swobodnie tam przeprowadzonego spisu ludności były rzetelne.

2. Uzyskanie przez greckie rodziny, które opuściły Albanię w czasie rządów komunistycznych, prawa do powrotu, z równoczesnym zwróceniem im utraconych majątków.

3. Zdecydowane potępienie i surowe karanie wszelkich incydentów na tle etnicznym przez albańskie władze i służby porządkowe.

Dzisiaj - mimo zapewnień Aten o przestrzeganiu międzynarodowych standardów w dziedzinie praw człowieka, należy ocenić, że położenie mniejszości albańskiej w Grecji nie jest dobre. Grecja, chcąc wypełniać - zgodnie z przepisami prawa europejskiego swoje zobowiązania wobec mniejszości, powinna je uznać i skupić się na ochronie ich praw. Ważne jest postępowanie zgodne z orzeczeniami Europejskiego Trybunału Praw Człowieka i zezwolenie na swobodne używanie terminu ,albański”, co dzisiaj jest zabronione. Niemniej mniejszość albańska w Grecji ma prawo do zakładania swych organizacji, towarzystw kulturalnych i wydawania czasopism w języku ojczystym bez wskazywania ich narodowego charakteru ${ }^{35}$.

Trudno przewidzieć, jakie będą relacje grecko-albańskie w przyszłości i jaki będzie miała na nie wpływ polityka wobec Czamów w Grecji i Greków w Albanii. Dzisiaj Grecy w Północnym Epirze mają swe szkoły, wsparcie ze strony greckiego kleru w prawosławnych cerkwiach, ponadto tworzą własne partie polityczne oraz towarzystwa kulturalno-oświatowe. Natomiast Grecja nie chce słyszeć o podjęciu dyskusji na temat utworzenia szkoły z albańskim językiem nauczania w Filiates (alb. Filat), czego domagają się

\footnotetext{
33 Ibidem, s. 8.

34 Po raz pierwszy w Albanii w 2004 r. przyznano, że Grecy oprócz stref mniejszościowych żyją także na innych terenach kraju.

35 Wskazania, jak powinno wyglądać demokratyczne przestrzeganie praw mniejszości religijnych, narodowych i etnicznych w Grecji, przedstawił w swym raporcie Gay McDouglas, zob. G. McDouglas, HUMAN RIGHTS COUNCIL Tenth session Agenda item 3. Report of the independent expert on minority issues, Gay McDougall, MISSION TO GREECE (8-16 September 2008), http://www2.ohchr.org/english/bodies/hrcouncil/ docs/10session/A.HRC.10.11.Add.3.pdf, (dostęp: 20.01.2016).
} 
mieszkańcy. Ponieważ dla Greków problem Czamów nie istnieje, Czamowie spotykają się z akceptacją swych dążeń jedynie w Albanii. Ważne jest natomiast poparcie, jakie uzyskała Tirana od Aten, gdy ubiegała się, by zostać członkiem NATO, oraz przychylne zapatrywanie się Greków na dążenia Albańczyków do członkostwa w Unii Europejskiej. Jest to $\mathrm{z}$ punktu widzenia Tirany ważniejsze $\mathrm{w}$ obecnej sytuacji niż przyznanie przez Ateny, że w Grecji żyją Albańczycy. W związku z prowadzeniem takiej polityki nie ma w Grecji zezwolenia na swobodne używanie terminu „albański”, zakładanie organizacji czy czasopism o charakterze narodowym. Brak też szkół z albańskim językiem wykładowym. Niemniej mniejszość albańska ma prawo do zakładania własnych organizacji, towarzystw kulturalnych i wydawania czasopism w języku swych ojców bez wskazywania ich narodowego charakteru.

\section{Bibliografia}

Dokumenty, raporty, rezolucje:

1. Aktet që kanë ndryshuar aktin e mësipërm, http://80.78.70.231/pls/kuv/kerkim_ndryshime2?a emertimi_ligjit=Ligj\&a_numri_aktit=10129\&a_viti_aktit=11.05.2009, (dostęp: 20.01.2016).

2. Albania, Country Information - US Department of Justice, http://www.justice.gov/sites/default/ fi les/eoir/legacy/2014/10/21/0403_Albania.pdf, (dostęp: 20.01.2016).

3. Democratic Cameria League, https://www.youtube.com/watch?v=DMJ7R6RJJfQ, (dostęp: 20.01.2016).

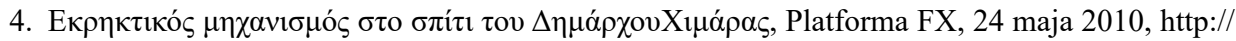
www.zougla.gr/page.ashx?pid=2\&aid=138350\&cid=4, (dostęp: 20.01.2016).

5. English - Offi ce of the High Commissioner on Human Rights, http://www2.ohchr.org/english/ bodies/hrcouncil/docs/10session/A.HRC.10.11.Add.3.pdf, (dostęp: 20.01.2016).

6. McDouglas G., HUMAN RIGHTS COUNCIL Tenth session Agenda item 3. Report of the independent expert on minority issues, Gay McDougall, MISSION TO GREECE (8-16 September 2008), http://www2.ohchr.org/english/bodies/hrcouncil/docs/10session/A.HRC.10.11. Add.3.pdf, (dostęp: 20.01. 2016).

7. Minoritetet etnike në Shqioëri, http://open.data.al/sq/lajme/lajm/lang/sq/id/673/Minoritetet-etnike-ne-Shqiperi, na stronach: Open Data - fundacionetic.org, (dostęp: 6.10.2015).

8. Office of the High Commissioner on Human Rights, Zays Alfred de, The International Judicial Protection of the Rights of Peoples and Minorities, http://alfreddezays.com/Chapbooks/ AMSTERDAM.shtml, [dostęp: 20.01.2016],

9. Organization for the European Minorities, http://www.eurominority.org/version/eng/minotity-detail.asp?id_pays=19\&id_minorites=gr-alba, także: http://archive.today/www.eurominority. org, (dostęp: 20.01.2016).

8. Resolution CM/ResCMN(2014)1 on the implementation of the Framework Convention for the Protection of National Minoritiesby Albania, https://wcd.coe.int/ViewDoc.jsp?id=2161315, (dostęp: 20.01.2016).

10. Stenogrami od OON (34), Šeeset i četvrta sednica održana vo Lake Success, New Jork vo ponedelnik, 9 septemvri 1946 godina vo 15 časot, w: „Fokus”, 2/1/2001, s. 50.

Monografie:

1. Azizaj A., Çështja e minoriteteve në plnin ndërkombëtar, për mbrojtjen e diplomës, Vlorë 2009.

2. Bonarek J., Czekalski T., Sprawski S., Turlej S., Historia Grecji, Kraków 2005.

3. Bilski R., Nie strzelajcie do nocnego ptaka. Batkany 1991-1998, Warszawa 1998. 
4. Cohen A., Two-dimensional man: An essay on power and symbolism in complex society, London 1974.

5. Cornell S., Hartmann D., Ethnicity and Race: Making Identities in a Changing World, Thousand Oaks, 1998.

6. Democracy and Ethnic Mobilization, red. J. Stein, London, New York 2000.

7. Halili R., Naród i jego pieśni. Rzecz o oralności, piśmienności i epice ludowej wśród Albańczyków i Serbów, Warszawa 2012.

8. Poulton H., The Balkans Minorities and States in Conflict, London 1993.

9. Smith A. D., Nationalism: Theory, Ideology, History, Polity, Cambridge 2001.

10. Stawowy-Kawka I., Albańczycy w Macedonii 1944-2001, Kraków 2014.

11. Trudgill P., On Dialect: Social and Geographical Perspectives, Oxford 1983.

12. Waldenberg M., Narody zależne i mniejszości narodowe w Europie Środkowo-Wschodniej. Dzieje konfliktów idei, Warszawa 2000.

Artykuły:

1. Balcerowicz P., Czy istnieja konflikty etniczne i religijne? [w:] Zaawansowane zapobieganie konfliktom, red. W. Kostecki, Warszawa 2011.

2. Czekalski T., Pótnocny Epir i Czamuria - współczesne oblicze sporu grecko-albańskiego, [w:] Naród - państwo - Europa Środkowa w XIX i XX wieku, red. A. Patek i W. Rojek, Kraków 2006, s. 312.

3. Hill P., Mehrsprachkeiten in Südosteuropa, „Zeitschrift für Balkanologie”, J.1990/26.

4. Pettifer J., The Greek Minority in Albania. Ethnic Minority in Post-communist State, [w:] The Politics of National Minority Participation in Post-communist Europe: State-building, Democracy, and Ethnic Mobilization, ed. J.P. Stein, New York 2000.

5. Smith D., Trends and Causes of Armed Conflict, http://edoc.vifapol.de/opus/volltexte/2011/2576/ pdf/smith_handbook.pdf, Edited version Aug. 2004, (dostęp: 20.01.2016).

6. M. Vickers, The Cham Issue: Albanian National and Property Claims in Greece, 2002, http:// www.albanianhistory.net/texts21/AH2002_1.html, (dostęp: 20.01.2016).

7. M. Vickers, The Greek Minority in Albania-Current Tensions, ,,Balkans Series” 10/02 http:// www.voltairenet.org/IMG/pdf/Greek_minority_in_Albania.pdf, (dostęp: 20.01.2016).

Irena Stawowy-Kawka

\section{The Influence of Minorities - Greek in Albania and Albanian in Greece - On Greek-Albanian Relations after 1991}

\section{Summary}

The article proves that both Greece and Albania saw a clear dependence of the minority policy from history and its exploitation in the current foreign policy. In Albania, the law, enacted by the communist authorities, is still in force, and so is the principle by which national minorities live exclusively in the so-called minority areas. With regard to the acquisition of Albanian or foreign citizenship, the government in Tirana applies the principle, which is in line with the declaration of the League of Nations, signed by Albania on 2 October, 1921, and even today, it cites this legal solution. Still, nationality it is dependent on the entry in the National Register of Births, Marriages and Deaths, in which the nationality of each Albanian citizen is determined. This law has been modifi ed by the authorities in Tirana as a result of pressure from the European Union. The situation of Albanians in Greece is even worse. The following are prohibited: free use of the term 'Albanian', 
setting up organisations or publishing national magazines. Also, there are no schools with the Albanian language as the medium of instruction in Greece. However, the Albanian minority has the right to establish their organisations, cultural societies and issue magazines published in the language of their fathers without specifying their national character.

Currently, Greeks in Albania have their schools, they enjoy the support for the Greek clergy in Orthodox churches and form their own political parties and associations of both a cultural and educational nature. In turn, Greece has no intention whatsoever of starting a discussion about the establishment of a school with the Albanian language as the medium of instruction in Filiates (known as Filat in Albanian), although such a demand has been presented by its residents. For the Greeks, the problem of the Chams (Albanians in Greece) does not exist, and the Cham people only have support for their eff orts in Albania. The support that Tirana received from Athens is signifi cant, when it was applying for NATO membership, and Greece's positive attitude towards the Albanians in their eff orts to join the European Union. From Tirana's point of view, it is much more crucial in the current situation than admitting by Athens that Albanians live in Greece.

Key words: the Albanians in Greece, the Greeks in Albania, the Balkans, ethnic minorities, Omonoia, Chameria 